\title{
Macroeconomic Environment and the Level of Cash Holding: A Literature Review
}

\author{
Yingxin Chen \\ Economy School, Jinan University, Guangzhou, China \\ Email: c_ying_xin@163.com
}

How to cite this paper: Chen, Y. X. (2021). Macroeconomic Environment and the Level of Cash Holding: A Literature Review. Open Journal of Social Sciences, 9, 263-271. https://doi.org/10.4236/jss.2021.91019

Received: December 18, 2020

Accepted: January 22, 2021

Published: January 25, 2021

Copyright $\odot 2021$ by author(s) and Scientific Research Publishing Inc. This work is licensed under the Creative Commons Attribution International License (CC BY 4.0).

\begin{abstract}
The level of corporate cash holding is mainly affected by micro factors. In the past 20 years, the relationship between the level of cash holding and macroeconomic environmental factors has attracted more and more attention. This paper first briefly discusses three traditional theories of the level of cash holding, and proposes the leading role of trade-off theory and pecking order theory in this topic. Then, it sorts the relevant literature on macroeconomic fluctuations and macroeconomic policies.
\end{abstract}

\section{Keywords}

Macroeconomic Environment, The Level of Cash Holding, Trade-Off Theory

\section{Introduction}

Because of its strong liquidity, cash, the "blood" of enterprises, is one of the important indicators of modern enterprise financial management. Since Keynes proposed the theory of money demand in 1936, the level of cash holding has been the focus of academic and industrial field. The research on the level of enterprises' cash holding is mainly carried out from two aspects: influencing factors and economic consequences, while the research on influencing factors mainly focuses on the internal aspect, such as enterprise life cycle (Faff et al., 2016), corporate governance environment (Dittmar and Mahrt-Smith, 2007), equity structure (Huang \& Ma, 2018). In fact, it should not only include the micro influencing factors inside the enterprise, but also include the macroeconomic factors since enterprise is located in the macro environment. Macroeconomic environment will have a general impact on a wide range of enterprises, while micro factors only consider the heterogeneity of enterprises. Therefore, macroeconomic environment will be an important factor which cannot be ignored in studying 
the level of enterprises' cash holding.

By studying the relevant literature on the macroeconomic environment and the level of cash holding, it can be found that scholars' researches on the factors of the macroeconomic environment mainly involves macroeconomic fluctuations (Gu et al., 2010; Anand et al., 2018) and macroeconomic policies (Baum et al., 2004; Deng \& Chen, 2015). This paper first briefly introduces the relevant theories on the level of corporate cash holdings, and then sorts the researches' results based on the macroeconomic fluctuations and macroeconomic policies.

\section{Theory of the Level of Cash Holding}

Since the 1970s, many scholars have mainly discussed the influencing factors on the level of cash holding from three traditional aspects: trade-off theory, pecking order theory and agency theory.

\subsection{Trade-Off Theory}

Trade-off theory holds the opinion that firms hold cash for transactional and preventive purposes. If the companies hold more cash, there will be more opportunity cost but less transaction cost; if the companies hold less cash, the opportunity cost is lower while the transaction cost is higher. Therefore, the companies need to trade off the transaction cost and opportunity cost, and the balance finally determines the optimal the level of cash holding of the enterprise. Opler et al. (1999) and Harford (1999) demonstrated the existence of the most optimal the level of cash holding for enterprises through empirical studies.

\subsection{Pecking Order Theory}

Myers \& Majlu (1984) put forward the pecking order theory in 1984, believing that in the case of transaction costs and information asymmetry, the financing order of enterprises is: internal financing, debt financing and equity financing. External investors ask for a higher risk premium due to information asymmetry. If the company has a surplus of retained earnings, it will pay down debt and accumulate cash. If the retained earnings are negative, the company will consume cash firstly and external financing will be consumed secondly. As a result, retained earnings are a major source of cash, which acts as a buffer for internal and external financing. In order to maximize the companies' value, enterprises tend to hold a large amount of cash with low financing cost to avoid external financing as much as possible. Based on this theory, it can know that there is no optimal level of cash holding.

\subsection{Agency Theory}

Jensen \& Meckling (1976) proposed agency theory, believing that there are agency costs between managers and shareholders. Shareholders tend to be risk-neutral group due to their diversified investments, while managers are risk avoiders. In order to avoid hostile takeovers, have more opportunities to invest, and consoli- 
date the power of managers, managers tend to hold more cash. On this basis, Jensen (1986) proposed the cash flow hypothesis, believing that based on their own situations, managers will hold more cash than enterprises actually need. Akhtar et al. (2018) believed that strong corporate governance would be conducive to reducing the agency cost of high the level of cash holding.

It can be found that there are two aspects to explain the cash holding behavior of an enterprise (Opler et al., 1999). Firstly, the level of cash holding in an enterprise is to smooth various frictions in economic operation. Secondly, there is a discussion with the level of cash holding from the perspective of corporate governance. Obviously, the trade-off theory and pecking order theory belong to the former, while the agency theory belongs to the latter. However, this paper mainly discusses the relationship between the macroeconomic environment and the level of corporate cash holdings. Enterprises hold a certain amount of corporate cash in order to smooth various frictions in economic operation situation. The agency cost theory proposed from the perspective of corporate governance is far from the influencing factors of the macroeconomic environment.

\section{The Influence of Macroeconomic Fluctuation on the Level of Cash Holding}

The research of macroeconomic fluctuation is divided into two parts: macroeconomic cycle and macroeconomic uncertainty.

\subsection{Macroeconomic Cycle}

Mitchell \& Gay (1927) divided the economic cycle into four stages: boom, depression, crisis and recovery. Existing studies generally divide a macroeconomic cycle into boom period and contraction period. That is, the crisis can be regarded as a turning point from prosperity to depression, while the recovery can be regarded as a turning point from depression to prosperity (Yang, 2010). Fluctuations in the economic cycle cause changes in the external environment of enterprises, and enterprises make corresponding adjustments in the level of cash holding to fit such changes (Anand et al., 2018).

Scholars at home and abroad have conducted more studies on this issue in recent years, and there is a consensus that enterprises hold less cash holding in economic boom period and more cash holding in economic recession period (Gu et al., 2010; Jiang \& Liu, 2011).

When it comes to the impact of macroeconomic environment, trade-off theory has been widely supported and recognized.

In the macroeconomic boom period, companies generally have good operating conditions, healthy balance sheets, low defaults, and low external financing costs. Enterprises generally hold a certain amount of cash based on transaction motivation, and the level is close to the "optimal holdings". In macroeconomic recession period, the enterprise operating performance deteriorate and default risks go up generally. Enterprises can be expected that the financing channels 
may be thwarted and external financing costs will rise in this situation. Based on the precautionary motive, the companies often hold a certain amount of cash, which tends to be larger than "optimal holdings". Thus, the dominant motivation for companies to hold cash varies at different stages of the economic cycle. It could be explained by the financial accelerator, which is because enterprise mortgage assets are pro-cyclical and agency costs are counter-cyclical (Bernanke et al., 1999). Enterprise's external financing cost and financing constraints also are counter-cyclical, which leads enterprise choose corresponding cash holdings through balancing the costs and benefits. As a result, the level of cash holding also has the counter-cyclical characteristics.

Especially in the period of financial crisis, the cost of adjusting cash holdings of enterprises increases significantly (Zhang \& Li, 2011), thus the behavior of holding cash with preventive motivation is more obvious (Pereira \& Morais, 2018).

\subsection{Macroeconomic Uncertainty}

Enterprises, however, are always adjust the corresponding cash holdings through the perception of macroeconomic uncertainty instead of the current of the economic cycle. Many scholars at home and abroad make the researches based on macroeconomic uncertainty (Baum et al., 2004; Baum et al., 2008; Gao et al., 2017; Smietanka et al., 2018; Deng \& Chen, 2015).

The more stable macroeconomic environment is, managers' prediction of the level of cash holding is more accurate. At the same time, the enterprises can show more uniqueness (Baum et al., 2004). When perceiving the uncertainty of the macro economy, the managers often increase the enterprises' the level of cash holding based on preventive motivation in order to smooth the uncertainty (Baum et al., 2004; Gao et al., 2017; Liang et al., 2012; Deng \& Chen, 2015). It could stabilize the step of the enterprises' growth, and reduce the uncertainty of the environment caused by the large operation fluctuations.

Due to the influence of macroeconomic cycle fluctuations, scholars broadened the perspective of research, such as industrial spatial clustering (Zheng \& Cheng, 2015), gender of senior executives (Zhou \& Xiu, 2015), and financing constraints (Almeida et al., 2004; Denis \& Sibilkov, 2009). Zheng \& Cheng (2015) found that when the economy was in a downward trend, the value effect of cash holdings in low-agglomeration enterprises significantly increased, and it will significantly increase with the financing constraint degree from competitors going up.

\section{The Influence of Macroeconomic Policy on the Level of Cash Holding}

Macroeconomic policy is formulated by the government to promote the steady and healthy development of the economy. Thus, it has the counter-cyclical characteristics. The implementation of macroeconomic policies will also affect the level of cash holding of enterprises (Anand et al., 2018; Li, 2018). The influence 
mechanism of macroeconomic policies includes two aspects: the specific implementation of macroeconomic regulatory policies (monetary policies and other macroeconomic policies) and macroeconomic policies uncertainty.

\subsection{Macroeconomic Regulatory Policies}

Many studies mainly focus on the impact of monetary policy on corporate cash holdings, and they agree that credit channel and interest rate channel play a major role in transmission (Jiang \& Yu, 2013).

1) Interest rate channel. The traditional interest rate channel of monetary policy holds that central banks can regulate economic activity by influencing shortterm nominal interest rates. This is due to price stickiness, and nominal interest rate can affect the real interest rate and thus the actual economic activity (Christiano et al., 2005). According to the inventory management theory of Tobin (1956), the level of cash holding can be regarded as an inventory management problem. It shows that the opportunity cost of cash holding is the interest rate of buying other securities (such as bonds), so the interest rate can measure the cost of cash holdings. When monetary policy is tight, the money supply is low, leading interest rates rising. It means that the money price of funds goes up, reducing cash holdings. Silva \& Adão (2018) used data from 1980 to 2013 in the United States finding that monetary policy can affect corporate cash holdings through interest rate channel, with nominal interest rate decreasing and corporate cash holdings increasing.

2) Credit channel. Due to the incomplete capital market and single source of financing, China's monetary policy is mainly transmitted through credit channel (Hu \& Xie, 2009). Zhou \& Jiang (2002) use the quarterly data from 1993 to 2001, finding that China's monetary policy is dominated by credit channel. This is because that bank credit is susceptible to the monetary policy, thus changing the supply of loanable funds (Mishkin, 1995; Suo \& Fan, 2007) and affecting the amount of external financing available. The tight monetary policy reduces the supply of credit, leading the external financing constraints strengthened, so the level of cash holding increases; in the period with loose monetary policy, the level of cash holding decreases (Zhu \& Lu, 2009).

No matter which transmission mechanism is based, monetary policy changes the scale and cost of financing, as well as the financing constraints of enterprises. Based on the precautionary motive, enterprises tend to hold a certain amount of cash in order to reduce the investment restrictions caused by financing constraints.

\subsection{Other Macroeconomic Regulatory Policies}

There are few researches on other macroeconomic regulatory policies. In terms of fiscal policy, Chen \& Liu (2010) proposed a transmission mechanism of fiscal policy to corporate cash flow: fiscal policy-macroeconomic overall level-micro enterprise-corporate cash flow. The implementation of the proactive fiscal pol- 
icy has caused excessive enthusiasm for public investment in the credit market and capital market, neglecting the financing needs of small and medium-sized state-owned, as well as private economies, which has a negative impact on the enterprises with strong financing constraints (Zhang, 2014).

In terms of industrial policies, with empirical research, Cheng (2016) found that the level of enterprises' cash holding would increase with the development of the market in the positive industrial policies. At the same time, enterprises with a higher the level of cash holding with the influence of industrial policies, would also have a higher value.

\subsection{Economic Policy Uncertainty}

Economic policy uncertainty refers to the perception that economic subjects cannot make accurate judgments on whether, when and how the government will make economic policies in the future. Scholars generally hold that as policy uncertainty increases, enterprises hold more cash (Li \& Shi, 2016; Cheng et al., 2018; Phan et al., 2019). Based on the trade-off theory and pecking order theory, the greater uncertainty of economic policies, the more information asymmetry strengthens the preventive motivation of enterprises, and the more difficulty of external financing. The role of information asymmetry on increasing the cash holdings of enterprises is enhanced (Zhu \& Sun, 2018). In the period of increasing uncertainty of economic policies, the cash holding speed of enterprises is also accelerated (Zhang et al., 2017).

In addition, scholars further add some variables of corporate governance to discuss the impact of macroeconomic environment on the level of cash holding, such as property right nature (Zhang et al., 2013; Zhang et al., 2017), enterprise group (Cai et al., 2015), internal control (Xu et al., 2015), and manager risk preference (Chen, 2018).

\section{Conclusion}

Many scholars have discussed this issue based on macro perspective in recent years. The traditional trade-off theory and pecking order theory have a strong explanatory power to explain the impact of macroeconomic environment on the level of cash holding of enterprises. Many scholars have discussed the aspects from macroeconomic fluctuations and macroeconomic policies: enterprises hold less cash during macroeconomic prosperity period, but more cash during economic recession period; the aspect of macroeconomic policy mainly shows that the monetary policy influences the financing constraints of enterprises through interest rate channel and credit channel, and the level of cash holding will be affected. Recently, considering the uncertainty of macro economy and macroeconomic policy, it is believed that enterprises will also increase the level of cash holding based on the precautionary motive.

In the future, as the capital market gradually being perfect and the financing channels gradually being rich, we need to focus on the interest rate channel of 
monetary policy. At the same time, the scholars can further combine micro and meso factors with macroeconomic factors, considering the connected effect among them. In this way, it can further enrich researches about the macroeconomic environment's influence on the level of corporate cash holding.

\section{Conflicts of Interest}

The author declares no conflicts of interest regarding the publication of this paper.

\section{References}

Akhtar, T., Tareq, M. A., Sakti, M. R. P. et al. (2018). Corporate Governance and Cash Holdings: The Way Forward. Qualitative Research in Financial Markets, 10, 152-170. https://doi.org/10.1108/QRFM-04-2017-0034

Almeida, H., Campello, M., \& Weisbach, M. S. (2004). The Cash Flow Sensitivity of Cash. The Journal of Finance, 59, 1777-1804. https://doi.org/10.1111/j.1540-6261.2004.00679.x

Anand, L., Thenmozhi, M., Varaiya, N. et al. (2018). Impact of Macroeconomic Factors on Cash Holdings? A Dynamic Panel Model. Journal of Emerging Market Finance, 17, S27-S53. https://doi.org/10.1177/0972652717751536

Baum, C. F., Caglayan, M. O., Ozkan, N. et al. (2004). The Impact of Macroeconomic Uncertainty on Cash Holdings for Non-Financial Firms (pp. 4-10). ZEW-Centre for European Economic Research Discussion Paper. https://doi.org/10.2139/ssrn.555952

Baum, C. F., Caglayan, M., Stephan, A. et al. (2008). Uncertainty Determinants of Corporate Liquidity. Economic Modelling, 25, 833-849.

https://doi.org/10.1016/j.econmod.2007.11.006

Bernanke, B. S., Gertler, M., \& Gilchrist, S. (1999). The Financial Accelerator in a Quantitative Business Cycle Framework. In Handbook of Macroeconomics (Vol. 1, pp. 13411393). Amsterdam: Elsevier. https://doi.org/10.1016/S1574-0048(99)10034-X

Cai, W., Zeng, C., \& Hu, Z. (2015). Business Group, Monetary Policy, and Corporate Cash Holdings. Financial Research, 2, 114-130.

Chen, H. (2018). Monetary Policy, Manager's Risk Preference Heterogeneity and Business. Investment Efficiency, 6, 96-101.

Chen, Z., \& Liu, J. (2010). Approach to Policy Effect on Corporate Cash Flow under the Background of Financial Crisis. Accounting Research, 4, 42-49.

Cheng, C. H. J., Chiu, C. W. J., Hankins, W. et al. (2018). Partisan Conflict, Policy Uncertainty and Aggregate Corporate Cash Holdings. Journal of Macroeconomics, 58, 78-90. https://doi.org/10.1016/j.jmacro.2018.08.010

Cheng, Y. (2016). How Do Macroeconomic Policies Affect the Economic Effects of Corporate Cash Holdings in Product and Capital Markets. China International Business, 2, 4-7.

Christiano, L. J., Eichenbaum, M., \& Evans, C. L. (2005). Nominal Rigidities and the Dynamic Effects of a Shock to Monetary Policy. Journal of Political Economy, 113, 1-45. https://doi.org/10.1086/426038

Deng, X., \& Chen, J. (2015). Macroeconomic Uncertainty, Information Asymmetry and Cash Holdings. Accounting Communication, 6, 86-89.

Denis, D. J., \& Sibilkov, V. (2009). Financial Constraints, Investment, and the Value of Cash Holdings. The Review of Financial Studies, 23, 247-269.

https://doi.org/10.1093/rfs/hhp031 
Dittmar, A., \& Mahrt-Smith, J. (2007). Corporate Governance and the Value of Cash Holdings. Journal of Financial Economics, 83, 599-634. https://doi.org/10.1016/j.jfineco.2005.12.006

Faff, R., Kwok, W. C., Podolski, E. J. et al. (2016). Do Corporate Policies Follow a LifeCycle? Journal of Banking \& Finance, 69, 95-107. https://doi.org/10.1016/j.jbankfin.2016.04.009

Gao, J., Grinstein, Y., \& Wang, W. (2017). Cash Holdings, Precautionary Motives, and Systematic Uncertainty. https://doi.org/10.2139/ssrn.2478349

Gu, N., Wan, X., \& Chen, H. (2010). Macroeconomic Conditions, Financial Constraints and Cash Holdings. China Management Studies, 5, 33-53.

Harford, J. (1999). Corporate Cash Reserves and Acquisitions. The Journal of Finance, 54, 1969-1997. https://doi.org/10.1111/0022-1082.00179

Hu, X., \& Xie, Y. (2009). Empirical Study of the Effectiveness of Monetary Policy through Credit Market in China, Journal of Zhongnan University of Economics and Law, 4, 58-63.

Huang, B., \& Ma, Y. (2018). The Influence of Ownership Concentration on Cash Holdings-Based on the Intermediary Effect of Large Shareholders' Occupying Funds. Research on Economics and Management, 11, 131-144.

Jensen, M. C. (1986). Agency Costs of Free Cash Flow, Corporate Finance, and Takeovers. The American Economic Review, 76, 323-329.

Jensen, M. C., \& Meckling, W. H. (1976). Theory of the Firm: Managerial Behavior, Agency Costs and Ownership Structure. Journal of Financial Economics, 3, 305-360.

https://doi.org/10.1016/0304-405X(76)90026-X

Jiang, C., \& Yu, H. (2013). Empirical Analysis of the Effectiveness of Credit Channel of China's Monetary Policy Transmission-And Its Influence on Cash Flow of Industrial Enterprises. Journal of Financial Development Research, 2, 10-15.

Jiang, L., \& Liu X. (2011). Study on Economic Cycle Fluctuation and Cash Holding Behavior of Listed Companies. Accounting Research, 9, 40-46.

Li, B. (2018). Monetary Policy, Financial Constraint and Corporate Cash Holdings. New Economics, 4, 22-30.

Li, F., \& Shi, Y. (2016). Economic Policy Uncertainty and Corporate Cash Holding Strategy: Empirical Research by Using China Economic Policy Uncertainty Index. Journal of Management Sciences in China, 19, 157-170.

Liang, Q., Tian, C., \& Zhan, X. (2012). Macroeconomic Uncertainty, Financial Constraints and Firm Cash Holdings in China. South China Journal of Economics, 4, 3-16.

Mishkin, F. S. (1995). Symposium on the Monetary Transmission Mechanism. Journal of Economic Perspectives, 9, 3-10. https://doi.org/10.1257/jep.9.4.3

Mitchell, W. C., \& Gay, E. F. (1927). Business Cycles: The Problem and Its Setting. New York: National Bureau of Economic Research.

Myers, S. C., \& Majluf, N. S. (1984). Corporate Financing and Investment Decisions When Firms Have Information That Investors Do Not Have. Journal of Financial Economics, 13, 187-221. https://doi.org/10.1016/0304-405X(84)90023-0

Opler, T., Pinkowitz, L., Stulz, R. et al. (1999).The Determinants and Implications of Corporate Cash Holdings. Journal of Financial Economics, 52, 3-46. https://doi.org/10.1016/S0304-405X(99)00003-3

Pereira Alves, P. F., \& Morais, F. (2018). Cash Holdings Are Increasing and Financial Crisis Strengths It. https://doi.org/10.2139/ssrn.3096566

Phan, H. V., Nguyen, N. H., Nguyen, H. T. et al. (2019). Policy Uncertainty and Firm 
Cash Holdings. Journal of Business Research, 95, 71-82. https://doi.org/10.1016/j.jbusres.2018.10.001

Silva, A. C., \& Adão, B. (2018). The Effect of Firm Cash Holdings on Monetary Policy. European Economic Review, 128, Article ID: 103508. https://doi.org/10.1016/j.euroecorev.2020.103508

Smietanka, P., Bloom, N., \& Mizen, P. (2018). Business Investment, Cash Holding and Uncertainty since the Great Financial Crisis. https://doi.org/10.2139/ssrn.3240493

Suo, Y., \& Fan, C. (2007). Can Monetary Policy Affect the Supply of Loans?-Empirical Evidence from Bank Portfolio Behavior. Journal of Economic Science,6, 57-65.

Tobin, J. (1956). The Interest-Elasticity of Transactions Demand for Cash. The Review of Economics and Statistics, 38, 241-247. https://doi.org/10.2307/1925776

Xu, R., Zhang, T., \& Zheng, J. (2015). Heterogeneity of Monetary Policy, Managers' Risk Preference and Enterprise Investment Efficiency. Accounting Communication, 9, 35-39.

Yang, Y. (2010). Review of Business Cycle Division. Market Modernization, 6, 158-160.

Zhang, C., Du, J., \& Su, K. (2013). Monetary Tightening, Nature of Property Rights and Corporate Cash Holdings. Industrial Economic Review, 4, 140-151.

Zhang, G., Qian, X., \& Xu, J. (2017). Can Economic Policy Uncertainty Affect Companies' Cash Holding Behavior?. Management Review, 29, 15-27.

Zhang, M., \& Li, Z. (2011). The Shock of Financial Crisis and the Dynamic Adjustment of Cash Holding. On Economic Problems, 8, 55-58.

Zhang, W. (2014). Cash Holdings and the Propagation Mechanism of Macroeconomic Factors: A Literature Review. Chinese Review of Financial Studies, 3, 111-123.

Zheng, L., \& Cheng, X. (2015). Business Cycle, Industrial Agglomeration and the Value Effect of Cash Holdings Policy. Financial Review, 7, 14-27.

Zhou, Y., \& Jiang, Z. (2002). Monetary Channel,Credit Channel and the Effectiveness of Monetary Policy. Journal of Financial Research, 9, 34-43.

Zhou, Z., \& Xiu, Z. (2015). Female Executives, Macroeconomic Environment and Cash Holdings. Economic Fabric, 4, 121-125.

Zhu, J., \& Lu, Z. (2009). Monetary Policies, Enterprise' Growth, and the Change in the Level of Cash-Holding. Management World, 3, 152-158.

Zhu, X., \& Sun, F. (2018). Economic Policy Uncertainty, Information Asymmetry and Corporate Cash Holdings. Commercial Accounting, 2, 29-32. 